\title{
DEVELOPMENT OF THE METHODOLOGICAL APPROACH OF OBTAINING PREPARATIONS BASED ON SOLID DISPERSIONS
}

\author{
(C) I. Kovalevska, O. Ruban
}

В даний час інноваційним напрямом фармацевтичної розробки є застосування методів підвищення біофармацевтичної ефективності та безпеки використання вже існуючих АФІ, в тому числі за рахунок їх включення у тверді дисперсії, в яких молекули речовини включаються в супрамолекулярні утворення за рахунок формування нековалентних зв'язків ексиипієнтами. На сьогодні отримання твердих дисперсій розглядається як найбільш ефективний спосіб підвищення біодоступності при пероральному прийомі, в якому розчинення носія сприяє вивільненню АФІ зі швидкою його солюбілізацією. За даними літератури встановлено, щзо на сьогодні існує тільки емпіричний підхід до отримання твердих дисперсій.

Метою роботи стало формулювання основних підходів до створення препаратів на основі твердих дисперсій з урахуванням сучасних напрямків розроблення складу та технології препаратів з важкорозчинними речовинами.

Матеріали та методи. Для розробки методологічного підходу використовували зовнішній ситуаційний контент-аналіз прикладних методів підвищення біодоступності активних фармацевтичних інгредієнтів, щзо застосовуються при виробництві твердих лікарських форм.

Результати. В ході виконання поставленої мети було запропоновано класифікацію типів твердих дисперсій залежно від структури і способу отримання, створено алгоритм з вибору способу отримання твердої дисперсії з урахування фізико-хімічних властивостей активних фармацевтичних інгредієнтів, який може бути використаний в технологічному процесі для посилення їх біодоступності. Також були виявлені критичні ланки при розробленні твердих дисперсій.

Висновки. 3 урахуванням фізико-хімічних властивостей активних фармацевтичних інгредієнтів визначено алгоритм з вибору способу отримання твердих дисперсій, який може бути використаний в технологічному процесі для покращення їх біодоступності. На підставі результатів аналізу даних літератури та власних досліджень щуодо фізико-хімічних характеристик активних фармацевтичних інгредієнтів та ексципієнтів, типу структури твердої дисперсії, виду розчинника та носія, запропоновано методологічний підхід до отримання твердих дисперсій, застосування якого дозволить оптимізувати процес розробки твердих лікарських форм

Ключові слова: тверді дисперсї̈, біодоступність, спосіб отримання, структура, методологічний підхід, етапи розроблення

\section{Introduction}

One of the perspective directions in the development of pharmaceutical technology now is the creation of dosage forms with solid dispersions that provide their optimal pharmacokinetic characteristics [1]. The obtaining of solid dispersions provides the opportunity to modify the physicochemical properties of an active pharmaceutical ingredient with an increase in the bioavailability class without losing a pharmacological action [2].

2. Formulation of the problem in a general way, the relevance of the theme and its connection with important scientific and practical issues

Bioavailability is one of the main pharmacokinetic properties of an active pharmaceutical ingredient (API). An important influence on its value is the solubility of the substance, which is an important physicochemical indicator that affects the absorption of the drug and its therapeutic efficacy. Unfortunately, up to $75 \%$ of APIs that are commercially available or under development are poorly soluble in the aquatic environment [3]. Different methods of increasing solubility exist for solving this problem, namely: the creation of solid dispersions, the production of salt, co-crystals, intermolecular complexes with polymers and oligomers, systems with surface-active substances, etc. Today, obtaining solid dispersions is considered as the most effective way to increase bioavailability in case of oral administration [4]. Therefore, the establishment of a methodological approach to obtaining preparations based on solid dispersions is an actual problem of pharmacy.

3. Analysis of recent studies and publications in which a solution of the problem are described and to which the author refers

The therapeutic efficacy of the drug usually depends on the adequate concentration of API, which is achieved and maintained at the site of action. Most drugs that administered orally are intended for release in various gastrointestinal sections and their bioavailability may differ according to the biopharmaceutical characteristics, depending on the properties of the API and the composition of the solid therapeutic system [5]. In order to increase the bioavailability, the method of solid dispersion (SD), which promotes increased bioavailability, optimization of release of API from the dosage form, elimination of side effects by reducing the used dose. Solid dispersion is a rather broad definition, which combines different types of "API-carrier" systems, obtained in various ways [6]. Today, there are three main methods of obtaining solid dispersions: melting, dissolving and coshredding. The most effective are considered a method of 
melting and dissolution, which will promote maximum intermolecular interaction of the API and the excipient [7].

\section{The field of research considering the general problem, which is described in the article}

According to the literature, it is established that there is only an empirical approach to obtaining solid dispersions. The main attention is paid to their classification, the method of obtaining, the establishment of physico-chemical characteristics without determining the possible relationship [8]. This slows the course of pharmaceutical development, increases the number of experiments, financial costs. Therefore, a methodological approach to the selection of rational technology and composition is needed to create drugs based on solid dispersions.

\section{Formulation of goals (tasks) of article}

Taking into account modern directions of development of composition and technology of drugs with difficult soluble substances to formulate the basic approaches to the preparation of drugs on the basis of solid dispersions.

\section{Presentation of the main research material (methods and objects) with the justification of the results}

The proposed methodology for the design of drugs based on solid dispersions is based on the implementation of a complex of marketing, physico-chemical, technological, biopharmaceutical and economic research, ensuring compliance of the developed drugs with current requirements from the standpoint of assessing their competitiveness in modern conditions. It includes 3 research blocks, each of which ends with an intermediate result, which provides the task setting for the next stages of the study.

The first block includes marketing research and is carried out in two stages: the analysis of literature data and the study of the state of the pharmaceutical market for the analogues of the preparation planned for development (analysis of the competitive environment). The task of the first stage of the study is to identify current priority approaches to the treatment of target pathology.

At the first stage in the development of composition and technology, it is first necessary to determine the physicochemical properties and the bioavailability class of the biopharmaceutical classification system (BSC) of the active pharmaceutical ingredient in order to further determine the feasibility of obtaining a solid dispersion, composition and technology.

The second block includes the following stages of technological research:

- preliminary research (study of physicochemical and technological properties of APIs and excipients, investigation of possible interaction between APIs and excipients, their correlation, development of methods of analysis of APIs in the presence of excipients). Determination of solid dispersion type and method of its obtaining;

- design of the composition (selection of qualitative and quantitative composition of the drug, studying the impact of the excipients on the technological properties of the mass for tabletting);
- development of the manufacture technology of the drug and methods of quality control (determination of technological regimes of production, assessment of stability and standardization of developed drugs) (Fig. 1).

When performing the stages of the second block, the necessary indicators of quality of the developed drug are developed. Each of the stages of the second block is a multi-level research system, the results of which are interconnected and determine the sequence of their implementation. In the offered algorithm the characteristic features of obtaining solid dispersions with methods of control of the obtained indicators are determined. The result of the second block of research is the creation of a drug based on solid dispersions that meet the requirements of regulatory documents, as well as the definition of standards of quality and development of regulatory documents.

One of the critical parameters in the second block of research is the establishment of the type of dispersion. This one will determine how to get dispersion. Therefore, in order to determine the algorithm for obtaining a solid dispersion, depending on its type, the data of literature on the dependence of the method of obtaining on the properties of the excipients was generalized (Tab. 1).

It is known that solid dispersions can be divided into 6 types depending on the physical state [9]. A special place is occupied by solid dispersions type M-C and M-A, which belong to colloid systems, the size of API particles in which less than $100 \mathrm{~nm}$. They have the highest physico-chemical parameters, which are formed due to the molecular interaction between the API and the carrier and are accompanied by the formation of cocrystals. But the ways to get them are complex and have features unlike the first four types.

When choosing the method of obtaining dispersions it is necessary to take into account that solid dispersions $\mathrm{C}-\mathrm{C}$ and $\mathrm{C}-\mathrm{A}$ belong to coarse-dispersed systems and have a crystalline form of API, therefore their preparation will contribute to increasing solubility without loss of thermodynamic equilibrium after formation for a long time. Type A-C has a limited mixing with the carrier of the crystalline structure, which will result in a system with high solubility, but unstable behavior in the process and storage. Therefore, it is necessary to add to their composition auxiliary substances that stabilize their thermodynamic parameters during storage [10].

Thus, using all of these aspects of creating solid dispersions, an algorithm was proposed for choosing a method for obtaining it, taking into account the physical and chemical properties of active pharmaceutical ingredients (Fig. 2). As can be seen from the figure, the choice of solvent or carrier is rather problematic.

A melting method that has a sufficient output of finished products and can be applied in the case of using a thermostable API must contribute to the formation of an eutectic mixture. The key point at this stage is to set the melting and glazing temperature, such as the API structure. The temperature of obtaining a solid dispersion depends on those parameters [11]. Also a significant factor is the chemical nature of the carrier, on which the place of release depends, the degree of intermolecular interactions and the mechanism of the formation of solid dispersion. 
The dissolution method implies not only the good solubility of the API in one fluid or another, but also takes into account the possibility of the effect of the solvent type on the choice of equipment during the technological process [12].

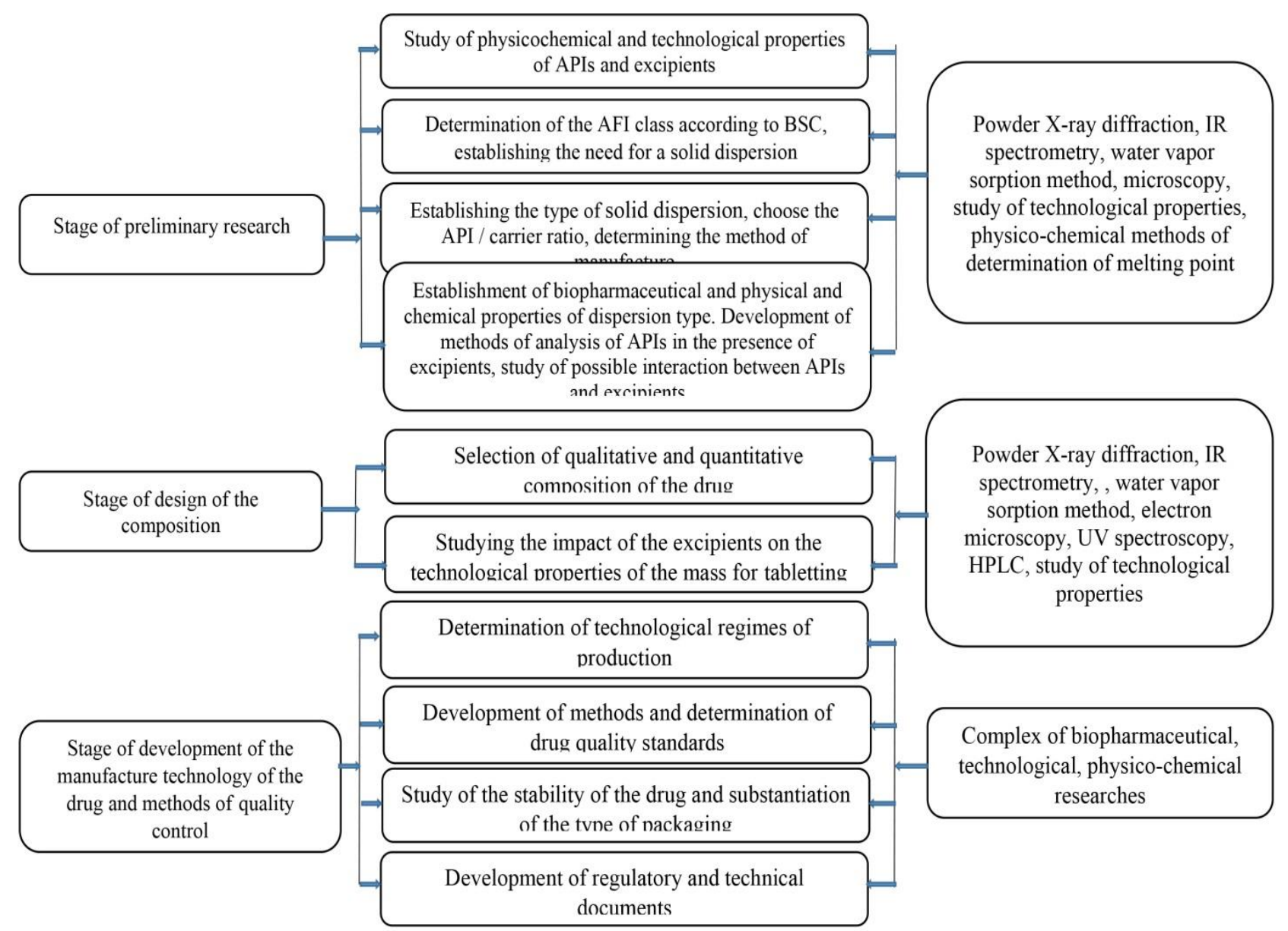

Fig. 1. Stages of the technological unit research in the development of drugs based on solid dispersions

Algorithm for choosing a method for obtaining a solid dispersion depending on the type of solid dispersion

\begin{tabular}{|l|l|}
\hline Type of solid dispersion & Method for obtaining, features \\
\hline $\mathrm{C}-\mathrm{C} ;$ crystalline API - crystalline carrier & $\begin{array}{l}\text { Combined grinding } \\
\text { Melting method (slow cooling rate) } \\
\text { Dissolution method (slow evaporation) }\end{array}$ \\
\hline $\mathrm{C}-\mathrm{A}$; crystalline API - amorphous carrier & $\begin{array}{l}\text { Combined grinding } \\
\text { Melting method (high cooling rate) } \\
\text { Dissolution method (quick evaporation) }\end{array}$ \\
\hline $\begin{array}{l}\mathrm{A}-\mathrm{C} ; \text { amorphous API - crystalline carrier } \\
\text { A }-\mathrm{A} ; \text { amorphous API - amorphous carrier } \\
\text { carrier }\end{array}$ & $\begin{array}{l}\text { Melting method (slow cooling rate) } \\
\text { Dissolution method (slow evaporation) }\end{array}$ \\
\hline $\begin{array}{l}\mathrm{M}-\mathrm{A} ; \text { molecular API dispersed in amorphous } \\
\text { carrier }\end{array}$ & $\begin{array}{l}\text { Melting method: spraying lyophile drying, rapid drying. } \\
\text { Dissolution method: lyophile drying }\end{array}$ \\
\hline
\end{tabular}




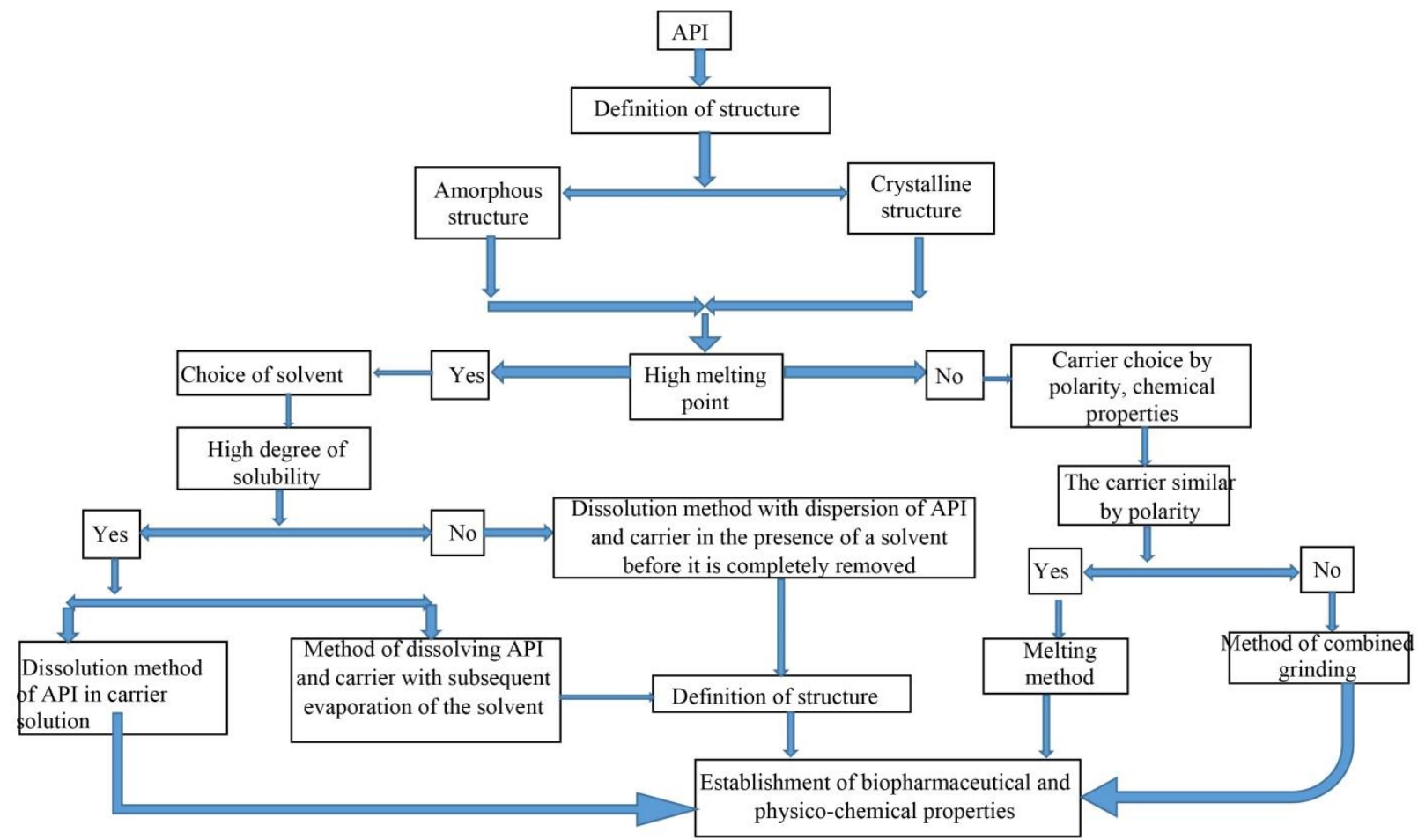

Fig. 2. The algorithm for choosing a method for obtaining a solid dispersion taking into account the physical and chemical properties of the APIs

The type of dispersion, possible interaction and other properties are determined by a complex of physical and chemical studies, which include powder X-ray diffraction, IR spectrometry, water vapour sorption method, electron microscopy, UV spectroscopy. The powder diffraction method is used for qualitative determination of materials having a crystalline structure. According to the intensity and shape of the diffraction peaks, the crystallinity of the materials is determined. Derivatographic studies are used to determine the amount of crystalline material. The IR spectroscopy is used to record the change in the energy distribution of interactions between the API and the matrix. The method of sorption of water vapor is used to study the affinity of solid dispersion to water. Electronic microscopy is used to study the morphology of solid dispersions [13].

The final block of research on the development of medicinal products includes an assessment of the bioequivalence of the developed dosage forms, the economic evaluation of the developed drugs, as well as a comprehensive assessment of the prognosis of the competitiveness of the developed drugs at the preclinical stage of their creation.

\section{Conclusions from the conducted research} and prospects for further development of this field

1. As the growing proportion of drugs in development, in its composition has poorly soluble substances, technologies for increasing their bioavailability have become an integral part of pharmaceutical development. The production of solid dispersions is one of such technologies, which in recent years is widely used in the manufacture of solid dosage forms. However, in spite of significant progress in understanding the nature of solid dispersions, there was no methodological approach to obtaining them.

2. Based on the physicochemical properties of active pharmaceutical ingredients, an algorithm is chosen to select a method for obtaining solid dispersions that can be used in the technological process to improve their bioavailability.

3. Based on the results of the analysis of literature data and own research on the physico-chemical characteristics of active pharmaceutical ingredients and excipients, such as the structure of solid dispersion, the type of solvent and carrier, a methodological approach to obtaining solid dispersions is proposed, the application of which will allow to optimize the process of development of solid dosage forms on their basis.

\section{References}

1. Enhancement of solubilization and bioavailability of poorly soluble drugs by physical and chemical modifications: A recent review / Chaudhary A. et. al. // Journal of Advanced Pharmacy Education \& Research. 2012. Vol. 2, Issue 1. P. 32-67. URL: https://pdfs.semanticscholar.org/1e5b/91e6a3964fa84e49b901051d5ca4bccc620d.pdf (Last accessed: 06.03.2018)

2. Perspektivy polucheniya lekarstvennykh form na osnove tverdykh dispersiy furatsilina / Krasnyuk I. I. et. al. // Razrabotka i registratsiya lekarstvennykh sredstv. 2015. Issue 11. URL: https://pharmjournal.ru/articles/stati/perspektivy-polucheniyalekarstvennyh-form-na-osnove-tvyordyh-dispersij-furacilina-n11-maj-2015 (Last accessed: 30.03.2017)

3. Grass M. Selecting In Vitro Dissolution Tests for Bioavailability Enhancing Oral Formulations. 2017. URL: https://www.americanpharmaceuticalreview.com/Featured-Articles/343542-Selecting-em-In-Vitro-em-Dissolution-Tests-for-

Bioavailability-Enhancing-Oral-Formulations/ (Last accessed: 11.03.2018) 
4. Huang Y., Dai W.-G. Fundamental aspects of solid dispersion technology for poorly soluble drugs // Acta Pharmaceutica Sinica B. 2014. Vol. 4, Issue 1. P. 18-25. doi: http://doi.org/10.1016/j.apsb.2013.11.001

5. Mir K. B., Khan N. A. Solid dispersion: overview of the technology // International Journal Of Pharmaceutical Sciences And Research. 2017. Vol. 8, Issue 6. P. 2378-2387. doi: http://doi.org/10.13040/ijpsr.0975-8232.8(6).2378-87

6. Singh S., Singh Baghe R., Yadav L. A review on solid dispersion // International Journal of Pharmacy \& Life Sciences. Vol. 2, Issue 9. P. 1078-1095. URL: http://www.ijplsjournal.com/issues\%20PDF\%20files/sep2011/11.pdf (Last accessed: 02.03.2018)

7. Harris R. Solid Dispersions. A universal formulation strategy for poorly soluble drugs? // Contract Pharma. 2016. URL: https://www.contractpharma.com/issues/2016-04-01/view_features/solid-dispersions-a-universal-formulation-strategy-for-poorlysoluble-drugs (Last accessed: 14.04.2018)

8. Dhirendra K., Lewis S., Udupa N., Atin K. Solid Dispersions: A Review // Pakistan journal of pharmaceutical sciences. 2009. Vol. 22, Issue 2. P. 234-246. URL: https://www.researchgate.net/publication/24250932_Solid_Dispersions_A_Review (Last accessed: 02.03.2018)

9. Kovalevska I. V., Ruban O. A., Hrudko V. A. Doslidzhennia vyvilnennia kvertsetynu z tverdykh dyspersii vysokomolekuliarnykh rechovyn // Zbirnyk naukovykh prats spivrobitnykiv NMAPO im. P. L. Shupyka. 2015. Issue 24 (5). P. 318-322. URL: http://nbuv.gov.ua/UJRN/Znpsnmapo_2015_24\%285\%29_62

10. Kovalevska I. V., Grudko V. A. Doslidzhennia tysku na rozchynnist kvertsetynu // Ukrainskyi visnyk psykhonevrolohii. 2014. Vol. 22, Issue 2 (79). P. 275-277.

11. Shmyreva Yu., Shmal'ts D., Bryuneman E. Povyshenie rastvorimosti metodom tverdoy dispersii s ispol'zovaniem proizvodnykh tsellyulozy: kontseptsiya, protsessy i obespechenie kachestva // Farmatsevticheskaya otrasl. 2015. Issue 6 (53). P. $70-73$. URL: http://promoboz.com/uploads/articles/372.pdf

12. An Exhaustive Review on Solubility Enhancement for Hydrophobic Compounds by Possible Applications of Novel Techniques / Alexander A. et. al. // Trends in Applied Sciences Research. 2012. Vol. 7, Issue 8. P. 596-619. doi: http://doi.org/10.3923/tasr.2012.596.619

13. Study of physical and chemical properties of solid dispersions of quercetin / Kovalevska I. V. et. al. // Asian Journal of Pharmaceutics. 2017. Vol. 11, Issue 4. P. 805-809.

Дата надходження рукопису 05.07.2018

Inna Kovalevska, PhD, Associate Professor, Department of Industrial Technology of Drugs, National University of Pharmacy, Pushkinska str., 53, Kharkiv, Ukraine, 61002

E-mail: inga.kovalevskaya@gmail.com

Olena Ruban, Doctor of Pharmaceutical Sciences, Professor, Head of Department, Department of Industrial Technology of Drugs, National University of Pharmacy, Pushkinska str., 53, Kharkiv, Ukraine, 61002

E-mail: ruban_elen@ukr.net 